OPEN ACCESS

Edited by:

Cicero Matthew R. Habito,

Massachusetts General Hospital,

USA

Reviewed by:

Meetu Kaushik,

Yale University, USA

Goutam Chakraborty,

Memorial Sloan Kettering Cancer

Center, USA

Naranamangalam Raghunathan Jagannathan,

All India Institute of Medical Sciences,

India

*Correspondence:

Zaver M. Bhujwalla

zaver@mri.jhu.edu

Specialty section:

This article was submitted to Cancer Imaging and Diagnosis, a section of the journal

Frontiers in Oncology

Received: 23 March 2016 Accepted: 09 December 2016

Published: 22 December 2016

Citation:

Mori N, Wildes F, Takagi T, Glunde K and Bhujwalla ZM (2016) The Tumor Microenvironment Modulates Choline and Lipid Metabolism.

Front. Oncol. 6:262.

doi: 10.3389/fonc.2016.00262

\section{The Tumor Microenvironment Modulates Choline and Lipid Metabolism}

\author{
Noriko Mori', Flonné Wildes' ${ }^{1}$, Tomoyo Takagi ${ }^{1}$, Kristine Glunde ${ }^{1,2}$ and \\ Zaver M. Bhujwalla ${ }^{1,2 *}$
}

' JHU ICMIC Program, Division of Cancer Imaging Research, The Russell H. Morgan Department of Radiology and Radiological Science, Baltimore, MD, USA, ${ }^{2}$ Sidney Kimmel Comprehensive Cancer Center, School of Medicine, The Johns Hopkins University, Baltimore, MD, USA

An increase of cellular phosphocholine (PC) and total choline (tCho)-containing compounds as well as alterations in lipids have been consistently observed in cancer cells and tissue. These metabolic changes are closely related to malignant transformation, invasion, and metastasis. The study of cancer cells in culture plays an important role in understanding mechanisms leading to altered choline (Cho) and lipid metabolism in cancer, as it provides a carefully controlled environment. However, a solid tumor is a complex system with a unique tumor microenvironment frequently containing hypoxic and acidic regions and areas of nutrient deprivation and necrosis. Cancer cell-stromal cell interactions and the extracellular matrix may also alter Cho and lipid metabolism. Human tumor xenograft models in mice are useful to mimic the growth of human cancers and provide insights into the influence of in vivo conditions on metabolism. Here, we have compared metabolites, obtained with high resolution ${ }^{1} \mathrm{H}$ MRS of extracts from human breast and prostate cancer cells in a 2-dimensional (2D) monolayer culture and from solid tumor xenografts derived from these cells, as well as the protein expression of enzymes that regulate Cho and lipid metabolism. Our data demonstrate significant differences in Cho and lipid metabolism and protein expression patterns between human breast and prostate cancer cells in culture and in tumors derived from these cells. These data highlight the influence of the tumor microenvironment on Cho and lipid metabolism.

Keywords: choline metabolism, lipid metabolism, choline kinase, breast cancer, prostate cancer, cell culture, xenograft model

\section{INTRODUCTION}

A solid tumor is a complex system with a unique microenvironment that frequently contains areas of hypoxia, extracellular acidosis, and necrosis (1). Cancer cell-stromal/endothelial cell interactions and nutrient deprivation are some of the additional factors that influence metabolism in solid tumors

Abbreviations: Cho, choline; Chk, choline kinase; GPC, glycerophosphocholine; ER, estrogen receptor; FASN, fatty acid synthase; MRS, magnetic resonance spectroscopy; PC, phosphocholine; PL, phospholipase; PR, progesterone receptor; PtdCho, phosphatidylcholine; PtdE, phosphatidylethanolamine; tCho, total choline; TMS, tetramethylsilane; TSP, 3-(trimethylsilyl) propionic $2,2,3,3-\mathrm{d}_{4}$ acid. 
(1-3). Although investigating cancer cell metabolism using cells in culture has the advantages of rapid use and lower costs, it is important to validate these results with tumor studies because of the complexities of solid tumor microenvironments that may alter metabolism and gene expression profiles compared to cells in culture. This is important in the development of biomarkers and in identifying targets for cancer treatment.

Cancer cells display aberrant choline (Cho) and lipid metabolism. Phosphatidylcholine (PtdCho), the most abundant phospholipid in eukaryotic cell membranes, contributes to proliferative growth and programed cell death (4). High levels of cellular phosphocholine (PC) and total choline-containing compounds [tCho: the sum of Cho, PC, and glycerophosphocholine (GPC)] have been consistently observed in cancer cells and tumor tissue and are closely related to malignant transformation, invasion, and metastasis (5-12).

Among the enzymes that regulate Cho metabolism, overexpression of choline kinase (Chk), the enzyme that catalyzes the phosphorylation of Cho to yield PC in the first step of PtdCho biosynthesis (Kennedy pathway) $(13,14)$, is a major cause of increased PC and tCho observed in cancers $(8,11,15)$. The elevated tCho level detected by ${ }^{1} \mathrm{H}$ magnetic resonance spectroscopy (MRS) is being evaluated as a specific biomarker of prostate cancer, and high tCho is associated with aggressiveness in breast cancer $(11,16)$. Downregulation of Chk- $\alpha$ has been shown to significantly reduce proliferation in breast cancer cells $(17,18)$ and tumors (9). Enzymes that control the catabolism of PtdCho include phospholipase A (PLA), PLC, and PLD. These enzymes maintain PtdCho levels. Cytosolic phospholipase $\mathrm{A}_{2}\left(\mathrm{cPLA}_{2} \alpha\right)$ has significantly different expression levels in basal-like and luminal-like breast cancer xenografts (19). $\mathrm{PLD}_{1}$ is upregulated in various human cancers, including breast $(20,21)$, uterine (22), and endometrial (23) cancers. An association between $\mathrm{PLD}_{1}$ and Chk- $\alpha$ expression with breast cancer malignancy was recently observed (21). Deregulated Cho phospholipid metabolism is emerging as a metabolic hallmark of oncogenesis and tumor progression.

Lipids function as energy storage molecules, structural components of cell membranes, and signaling molecules involved in cell growth, inflammation, and immunity $(24,25)$. Increased lipid biosynthesis is a characteristic feature of cancer. Elevated de novo fatty acid synthesis is necessary for rapidly proliferating tumor cells to continually provide lipids, such as phospholipids, for membrane production. Proton spectroscopy of lipid-soluble cancer cell and tumor extracts detects signals from fatty acids, cholesterol, and phospholipids. Fatty acid synthase (FASN) is an important lipogenic enzyme required for fatty acid synthesis. FASN overexpression has been reported in several human cancers including breast, prostate, colon, and ovary and has been associated with poor prognosis (26-32).

Here, we obtained high resolution ${ }^{1} \mathrm{H}$ MR spectra of extracts from cancer cells, and the corresponding tumor xenografts derived from these cells, to identify differences in Cho and lipid metabolism between cells and tumors. We selected two human prostate (DU-145 and PC-3) and two human breast (MCF-7 and MDA-MB-231) cancer cell lines with different aggressiveness for these studies. Expression of Chk- $\alpha, \mathrm{CPLA}_{2}, \mathrm{PLD}_{1}$, and FASN was characterized in cells and tumors to understand the molecular mechanisms underlying the differences in Cho and lipid metabolism observed between cells and tumors. Significant differences in Cho metabolites, especially PC and tCho, were observed between cells and tumors that were reflected in the differences in enzyme expression. These results underline the importance of the tumor microenvironment and conditions that exist in vivo, in modulating the Cho and lipid metabolism of cells in tumors, and provide new insights into the regulation of these metabolic pathways.

\section{MATERIALS AND METHODS}

\section{Cell Culture}

Two prostate and two breast cancer cell lines were used in this study. PC-3 and DU-145 prostate cancer cells are both androgen independent, but PC-3 is more invasive and metastatic than DU-145 prostate cancer cells (33). MDA-MB-231 is a triple negative metastatic human breast cancer cell line, and MCF-7 is an estrogen receptor/progesterone receptor-positive poorly metastatic human breast cancer cell line (33). All cell lines were obtained from American Type Culture Collection (Manassas, VA, USA) and were maintained in a humidified atmosphere with $5 \% \mathrm{CO}_{2}$ in air, at $37^{\circ} \mathrm{C}$. The cell lines were grown in RPMI-1640 medium supplemented with $10 \%$ fetal bovine serum (SigmaAldrich, St. Louis, MO, USA) and 100 units/ml penicillin and $100 \mu \mathrm{g} / \mathrm{ml}$ streptomycin (Life Technologies Ltd., Grand Island, NY, USA).

\section{Generation of Tumor Xenografts}

Approximately $2 \times 10^{6}$ cells in $50 \mu \mathrm{L}$ Hanks' balanced salt solution (Sigma-Aldrich, St. Louis, MO, USA) were inoculated in the mammary fat pad (breast cancer cells) or the flank (prostate cancer cells) of severe combined immunodeficient mice. For MCF-7 tumors, a $17 \beta$-estradiol pellet $(0.18 \mathrm{mg}$ 90-day release pellet, Innovative Research of America, Sarasota, FL, USA) was implanted subcutaneously 2 days prior to cancer cell inoculation. Mice were fed with Teklad global $18 \%$ protein extruded rodent diet (Harlan, Madison, WI, USA) that includes $1,200 \mathrm{mg} / \mathrm{kg}$ of Cho, $0.9 \%$ total saturated fatty acids, and $4.7 \%$ of total unsaturated fatty acids with minerals, amino acids, vitamins, and no cholesterol.

\section{Dual-Phase Extraction of Cells and Tumors}

Cells were cultured to about $80 \%$ confluence, and medium was changed $3 \mathrm{~h}$ prior to cell collection to avoid any lack of nutrition. Adherent cells were collected by trypsinization and counted using a hemocytometer after staining dead cells with trypan blue. Approximately $4-5 \times 10^{7}$ cells were harvested for cell extraction. Solid tumors were excised at volumes of $\sim 200-500 \mathrm{~mm}^{3}$ $(\sim 0.2-0.4 \mathrm{~g})$ and immediately freeze-clamped in liquid $\mathrm{N}_{2}$. The time from cell inoculation to tumor excision was approximately 50 days for DU-145, 30 days for PC-3, 40 days for MCF-7, and 60 days for MDA-MB-231 tumors.

Both lipid- and water-soluble extract fractions were obtained using a dual-phase extraction method as described previously 
(17). Briefly, pelleted cells were mixed with $4 \mathrm{~mL}$ of ice-cold methanol and vigorously vortexed. For tumor samples, ground tumors in liquid $\mathrm{N}_{2}$ were mixed with $4 \mathrm{~mL}$ of ice-cold methanol and homogenized. After keeping samples on ice for $15 \mathrm{~min}, 4 \mathrm{~mL}$ of chloroform were added, vortexed vigorously, and kept on ice for $10 \mathrm{~min}$. Finally, $4 \mathrm{~mL}$ of water were added and shaken well. All operations were performed on ice, and samples were stored at $4^{\circ} \mathrm{C}$ overnight for phase separation and later centrifuged at $15,000 \mathrm{~g}$ at $4^{\circ} \mathrm{C}$ for $30 \mathrm{~min}$. The water/methanol phase containing water-soluble cellular metabolites such as Cho, PC, and GPC were treated with $\sim 100 \mathrm{mg}$ of chelex beads (Sigma-Aldrich, St. Louis, MO, USA) to remove any divalent cations. After removing the beads, methanol was evaporated using a rotary evaporator. The remaining water phase was lyophilized. The chloroform phase (lipid-soluble phase) was collected in the tube, and chloroform was evaporated using nitrogen gas. Both phases of the extracts were stored at $-20^{\circ} \mathrm{C}$ until use.

\section{Magnetic Resonance Spectroscopy}

Water-soluble extracts from cells and tumors were resuspended in $0.6 \mathrm{~mL}$ of deuterated water $\left(\mathrm{D}_{2} \mathrm{O}\right)$ containing $2.4 \times 10^{-7} \mathrm{~mol}$ of 3-(trimethylsilyl)propionic 2,2,3,3- $\mathrm{d}_{4}$ acid (TSP; Sigma-Aldrich, St. Louis, MO, USA) as an internal standard for MR spectral analysis. Lipid-soluble extracts were resuspended in $0.4 \mathrm{~mL}$ of chloroform-D and $0.2 \mathrm{~mL}$ of methanol-D4 with $0.05 \mathrm{v} / \mathrm{v} \%$ tetramethylsilane (TMS) (Cambridge Isotope Laboratories, Inc., Tewksbury, MA, USA) as an internal standard. Fully relaxed ${ }^{1} \mathrm{H}$ MR spectra of water-soluble extracts and lipid-soluble extracts were acquired on a Bruker Avance 11.7 T spectrometer (Bruker BioSpin Corp., Billerica, MA, USA) with flip angle $=30^{\circ}$, sweep width $=10,000 \mathrm{~Hz}$, repetition time $=11.2 \mathrm{~s}$, block size $=32 \mathrm{~K}$, and scans $=128$. MR spectra were analyzed using Bruker XWINNMR 3.5 software (Bruker BioSpin) as previously described (34). Signal integrals of $-\mathrm{N}^{+}\left(\mathrm{CH}_{3}\right)_{3}$ resonances of $\mathrm{PC}$ at $\sim 3.226 \mathrm{ppm}$, $\mathrm{GPC}$ at $\sim 3.235 \mathrm{ppm}$, and free Cho at $\sim 3.208 \mathrm{ppm}$ in water-soluble extracts were determined and normalized to cell number and cell volume and compared to the TSP standard. To determine concentrations of cell samples, peak integration $\left(I_{\mathrm{met}}\right)$ from ${ }^{1} \mathrm{H}$ spectra of PC, GPC, and Cho were compared to that of the internal standard TSP $\left(I_{\mathrm{TSP}}\right)$ according to the equation:

$$
\begin{gathered}
{\left[\text { metabolite }_{\text {cell }}\right]=A_{\mathrm{TSP}} \cdot \frac{I_{\mathrm{met}} / H}{\left(I_{\mathrm{TSP}} / H\right) \cdot N_{\text {cell }} \cdot V_{\text {cell }}}} \\
{\left[\text { metabolite }_{\text {tumor }}\right]=A_{\mathrm{TSP}} \cdot \frac{I_{\mathrm{met}} / H}{\left(I_{\mathrm{TSP}} / H\right) \cdot V_{\text {tumor }}}}
\end{gathered}
$$

In these equations, [metabolite cell $_{\text {] }}$ represents the intracellular concentration of the metabolite of interest expressed as mole per liter $(\mathrm{M}), A_{\text {TSP }}$ is the number of moles of TSP $\left(2.4 \times 10^{-7} \mathrm{~mol}\right)$ in the sample, $H$ is the number of protons contributing to the signal, $N_{\text {cell }}$ is the cell number, and $V_{\text {cell }}$ is the cell volume. To determine the cell volume, cell size was determined by trypsinizing the cells and measuring the diameter (d) of 100 randomly selected cells using an optical microscope and calculated as $\left[(4 \pi / 3) \times(d / 2)^{3}\right]$. The cell volumes used for calculation are
MDA-MB-231: 2,050 $\mu \mathrm{m}^{3}$, MCF-7: 3,128 $\mu \mathrm{m}^{3}$, PC-3: 3,120 $\mu \mathrm{m}^{3}$, and DU-145: 3,630 $\mu \mathrm{m}^{3}$ (7).

Tumor metabolite concentration [metabolite tumor $_{\text {] }}$ was calculated in mole per liter (M), $V_{\text {tumor }}$ is the tumor volume in liter (assuming $1 \mathrm{~g}=1 \mathrm{~mL}$ ).

In lipid phase samples, chemical shifts were referenced to the internal standard TMS resonance at $0 \mathrm{ppm}$ using published data (35-38). To determine the arbitrary unit (A.U.) of metabolites from lipid phase samples, signal integrals $\left(I_{\mathrm{met}}\right)$ of methyl groups assigned to $\mathrm{C}_{18}$ of cholesterol $\left(\mathrm{C}_{18}\right)$ at $\sim 0.7 \mathrm{ppm}$, methyl groups $\left(-\mathrm{CH}_{3}\right)$ at $\sim 0.9 \mathrm{ppm}$, methylene groups $\left(-\left(\mathrm{CH}_{2}\right) \mathrm{n}-\right)$ at $\sim 1.3 \mathrm{ppm}$, and ethylene groups $(-\mathrm{CH}=\mathrm{CH}-)$ at $\sim 5.4 \mathrm{ppm}$ in acyl chains of lipids, $-\mathrm{CH}_{2}-\mathrm{N}$ in phosphatidylethanolamine (PtdE) at $\sim 3.1 \mathrm{ppm}$, the Cho group $\left(-\mathrm{N}^{+}\left(\mathrm{CH}_{3}\right)_{3}\right)$ primarily from PtdCho at $\sim 3.2 \mathrm{ppm}$ peaks were determined and compared to that of TMS $\left(I_{\mathrm{TMS}}\right)$. A.U. values were standardized by cell number $\left(N_{\text {cell }}\right)$ or tumor weight (g) $\left(W_{\text {tumor }}\right)$. For the comparison of cells and tumors, ratios of A.U. values were used.

$$
\begin{aligned}
& \text { A.U./cell }=\frac{I_{\mathrm{met}} \cdot 10^{9}}{I_{\mathrm{TMS}} \cdot N_{\text {cell }}} \\
& \text { A.U./g }=\frac{I_{\mathrm{met}} \cdot 10}{I_{\mathrm{TMS}} \cdot W_{\text {tumor }}}
\end{aligned}
$$

\section{Immunoblot Analysis}

Cells were grown in culture medium and scraped into RIPA buffer [50 mM Tris, pH 7.4, $150 \mathrm{mM} \mathrm{NaCl}, 1 \mathrm{mM}$ EDTA, 1\% Triton-100, 1\% sodium deoxycholate, $1 \mathrm{mM}$ phenylmethylsulfonyl fluoride, $0.1 \%$ SDS, and a protease inhibitor cocktail at 1:200 dilution (Sigma-Aldrich, St. Louis, MO, USA)], and cell lysates were incubated on ice for $30 \mathrm{~min}$. Protein samples from tumors were prepared after grinding freeze-clamped tumors in lipid $\mathrm{N}_{2}$ and sonicating in Hepes buffer with a protease inhibitor cocktail. Cell and tumor lysates were spun down at 16,000 $\mathrm{g}$ (refrigerated centrifuge 5415 R, Eppendorf, Westbury, NY, USA) and $4^{\circ} \mathrm{C}$ twice. Protein concentrations were estimated using the Bio-Rad DC assay (Bio-Rad, Hercules, CA, USA). Equal amounts of total protein ( 40 or $50 \mu \mathrm{g}$ ) from cells or tumors were resolved on one-dimensional $7.5 \%$ SDS-PAGE gels and transferred to a nitrocellulose membrane (Bio-Rad). After blocking in 5\% milk-TBST (TBS Tween), the membrane was separately probed with a custom-made polyclonal Chk- $\alpha$ antibody (Proteintech Group, Inc., Chicago, IL, USA) (17), cPLA 2 antibody (Santa Cruz Biotechnology, Inc. Dallas, TX, USA), FASN antibody (Santa Cruz Biotechnology), and $\mathrm{PLD}_{1}$ antibody (Abcam, Cambridge, MA, USA). Anti-GAPDH antibody (Molecular Probes, Eugene, OR, USA) was used for equal loading assessment. Secondary antibodies were horseradish peroxidase conjugated anti-mouse or anti-rabbit IgG (Vector Laboratories, Burlingame, CA, USA). Reactions were recorded on Blue Bio film (Denville Scientific, Metuchen, NJ, USA) following use of Super Signal West Pico Substrate (Pierce Biotech, Rockford, IL, USA).

\section{Statistical Analysis}

Data were expressed as mean \pm SD. The statistical significance was evaluated using a two-tailed unpaired Student's $t$-test. $P$ values of 
less than 0.05 were considered to be significant unless otherwise stated. Four or more samples were used for cell culture data and tumor data.

\section{RESULTS}

\section{Levels of Cho Metabolites in Water-Soluble Extracts Determined by MRS}

Representative ${ }^{1} \mathrm{H}$ MR spectra of water-soluble metabolites obtained from PC-3 cells and a tumor extract are shown in Figure 1. Expanded Cho metabolite regions of water-soluble cell and tumor extract spectra from DU-145, PC-3, MCF-7, and MDA-MB-231 cell lines are shown in Figure 2 to demonstrate the differences in the pattern of Cho metabolites between the cell and tumor pairs. Data averaged over four cell studies and six tumors showed a consistent decrease of PC in tumors compared to cells in all four cell lines (Figure 3A). The two most aggressive cell lines (PC-3 and MDA-MB-231) showed the strongest decline of PC in tumors compared to cells. GPC tended to increase in tumors compared to cells in PC-3 and MDA-MB-231 with the exception of DU-145 cells where there was a significant decrease in tumors. The several fold decrease of PC overshadowed the small increase of GPC in tumors compared to cells, resulting in a significant decrease of tCho in PC-3, and MDA-MB-231 tumors compared to the cells. In DU-145 tumors, the decrease of both PC and GPC resulted in a significant decrease of tCho in tumors compared to the cells.

The PC/GPC ratio was higher in cells than in tumors (Figure 3B), and the differences were larger in the more malignant cell lines (PC-3 and MDA-MB-231) compared to the less malignant cell lines (DU-145 and MCF-7). Interestingly, the higher PC/GPC ratio observed in the more aggressive cell lines

\section{A PC-3 cell extract}

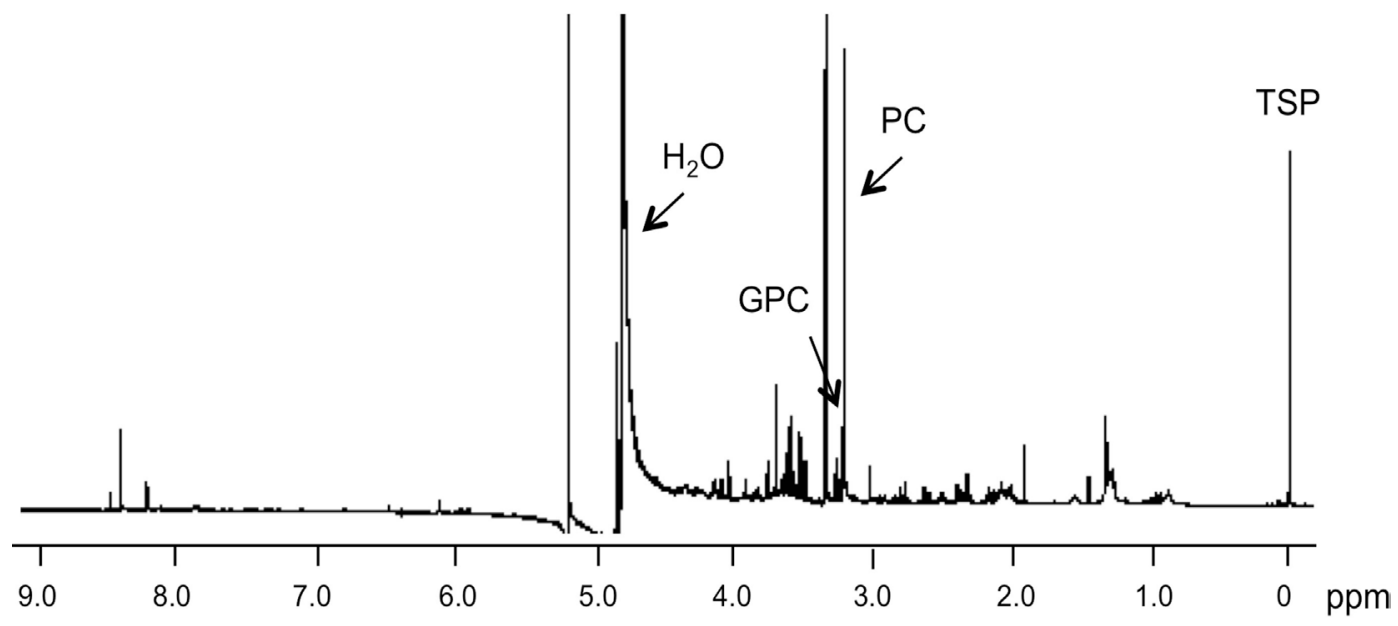

B PC-3 tumor extract

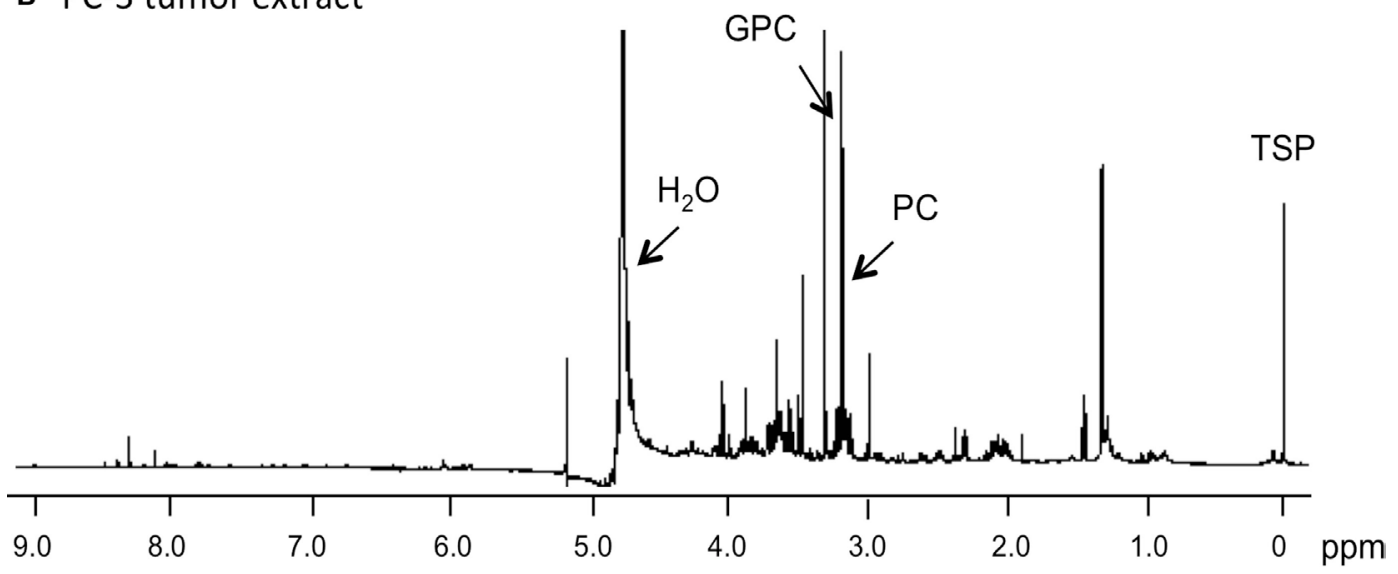

FIGURE 1 | Representative ${ }^{1} \mathbf{H}$ MR spectra obtained from water-soluble extracts of (A) PC-3 cells (4 $\times 10^{7}$ cells) and (B) PC-3 tumor xenograft (0.4 g) Spectra were acquired on a Bruker Avance $11.7 \mathrm{~T}$ spectrometer with a $30^{\circ}$ flip angle, $10,000 \mathrm{~Hz}$ sweep width, $11.2 \mathrm{~s}$ repetition time, $32 \mathrm{~K}$ block size, and 128 scans. TSP, 3-(trimethylsilyl)propionic 2,2,3,3- $\mathrm{d}_{4}$ acid, an internal standard at 0 ppm; PC, phosphocholine; GPC, glycerophosphocholine; $\mathrm{H}_{2} \mathrm{O}$, water signal. 

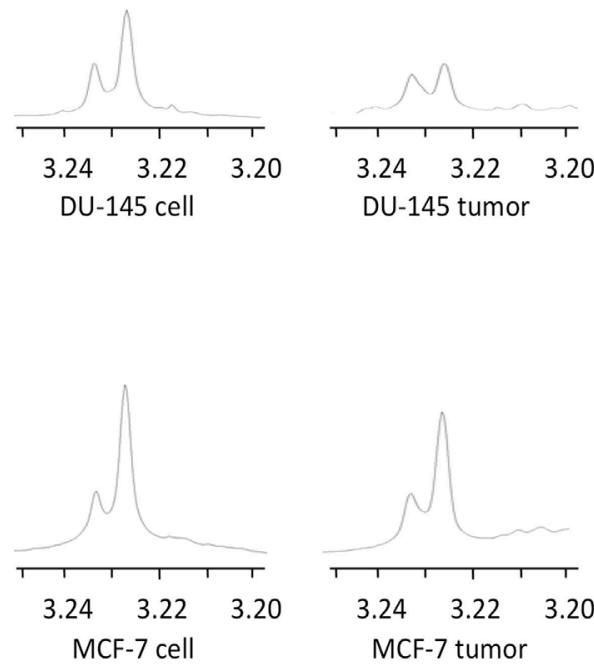

MCF-7 tumor
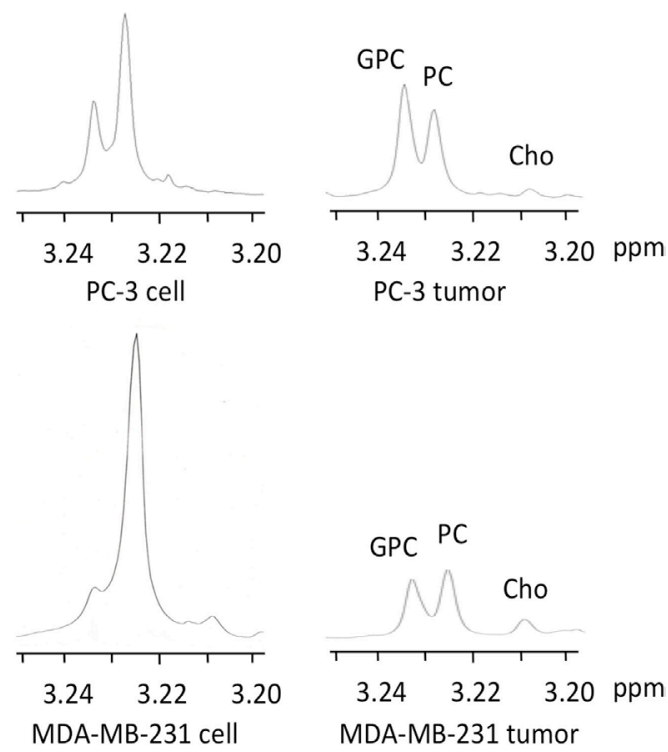

PC-3 tumor

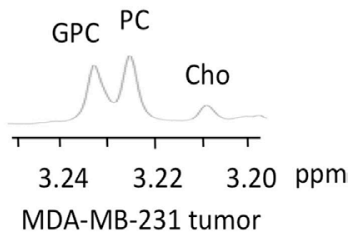

FIGURE 2 | Representative choline metabolite regions of ${ }^{1} \mathrm{H}$ MR spectra obtained from water-soluble extracts of DU-145, PC-3, MCF-7, and MDA-MB-231 cells and the corresponding tumor xenografts. Spectra are expanded to display signals from 3.20 to 3.25 ppm. Peak assignments are: free Cho at $\sim 3.208$ ppm, PC at $\sim 3.226$ ppm, and GPC at $\sim 3.235$ ppm.

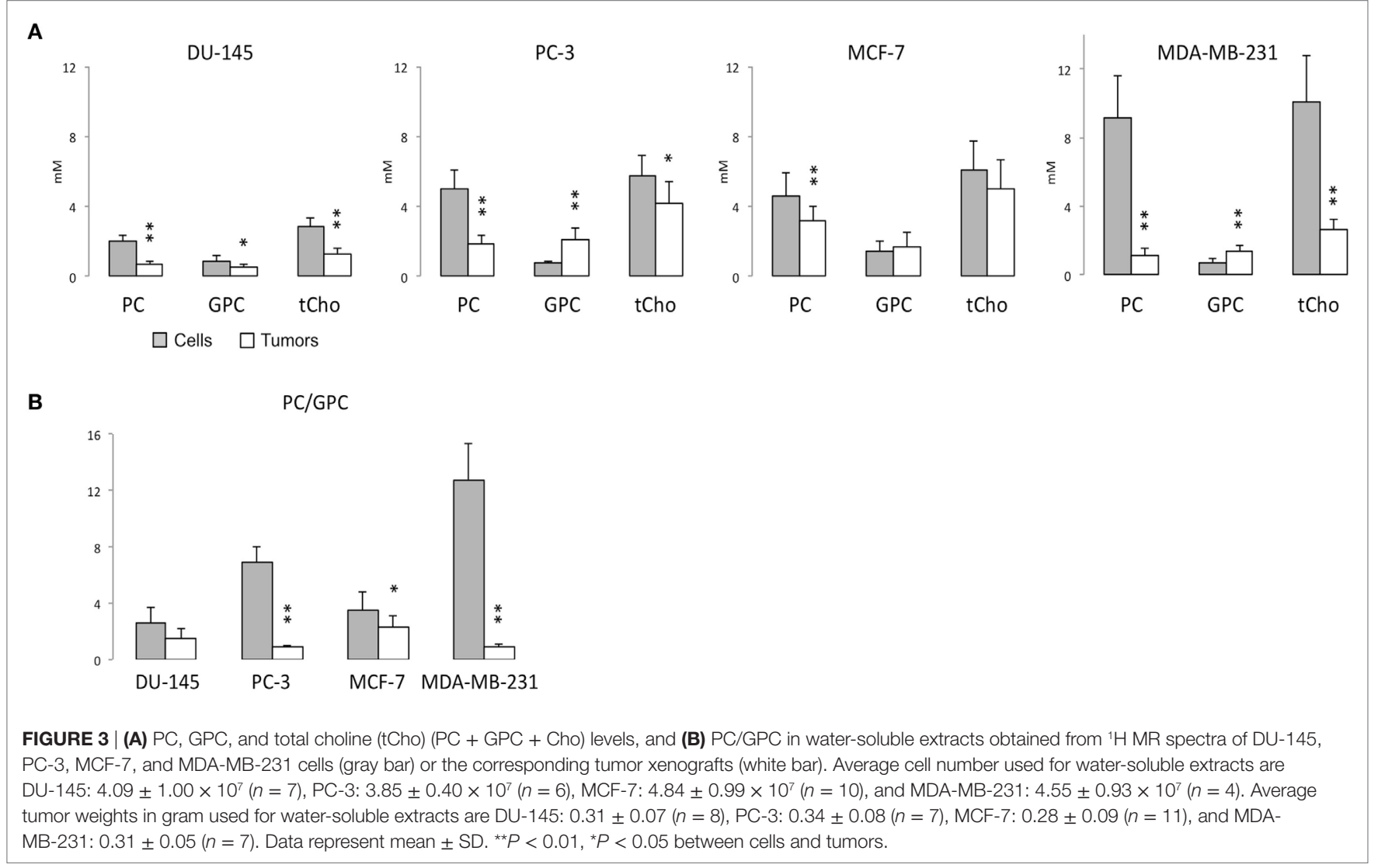


(PC-3 and MDA-MB-231) compared to the less aggressive cell lines (DU-145 and MCF-7) was not observed in tumor extracts.

\section{Levels of Lipid Metabolites in Lipid-Soluble Extracts Determined by MRS}

${ }^{1} \mathrm{H}$ MRS was used to compare lipid-soluble metabolites from cells and tumors. Representative ${ }^{1} \mathrm{H}$ MR spectra from MCF-7 cells are shown in Figure 4. Data summarized over multiple cell and tumor samples are presented as A.U./cell from cells in culture (Figure 5A) and A.U./g from tumors (Figure 5B). Data from the methyl groups assigned to $\mathrm{C}_{18}$ of cholesterol $\left(\mathrm{C}_{18}\right)$, the methyl groups $\left(-\mathrm{CH}_{3}\right)$, the methylene groups $\left(-\left(\mathrm{CH}_{2}\right) \mathrm{n}-\right)$, and ethylene groups $(-\mathrm{CH}=\mathrm{CH}-)$ in acyl chains of lipids, $-\mathrm{CH}_{2}-\mathrm{N}$ in PtdE, the Cho group $\left(-\mathrm{N}^{+}\left(\mathrm{CH}_{3}\right)_{3}\right)$ primarily from PtdCho are presented. To compare cells and tumors within the same cell lines, metabolite integrals were normalized to the $-\mathrm{CH}_{3}$ signal to obtain ratios of $\mathrm{C}_{18} /-\mathrm{CH}_{3},-\left(\mathrm{CH}_{2}\right) \mathrm{n}-/-\mathrm{CH}_{3}, \mathrm{PtdE} /-\mathrm{CH}_{3},-\mathrm{N}^{+}\left(\mathrm{CH}_{3}\right)_{3} /-\mathrm{CH}_{3}$, $-\mathrm{CH}=\mathrm{CH}-/-\mathrm{CH}_{3}$. Additional analysis was performed to obtain

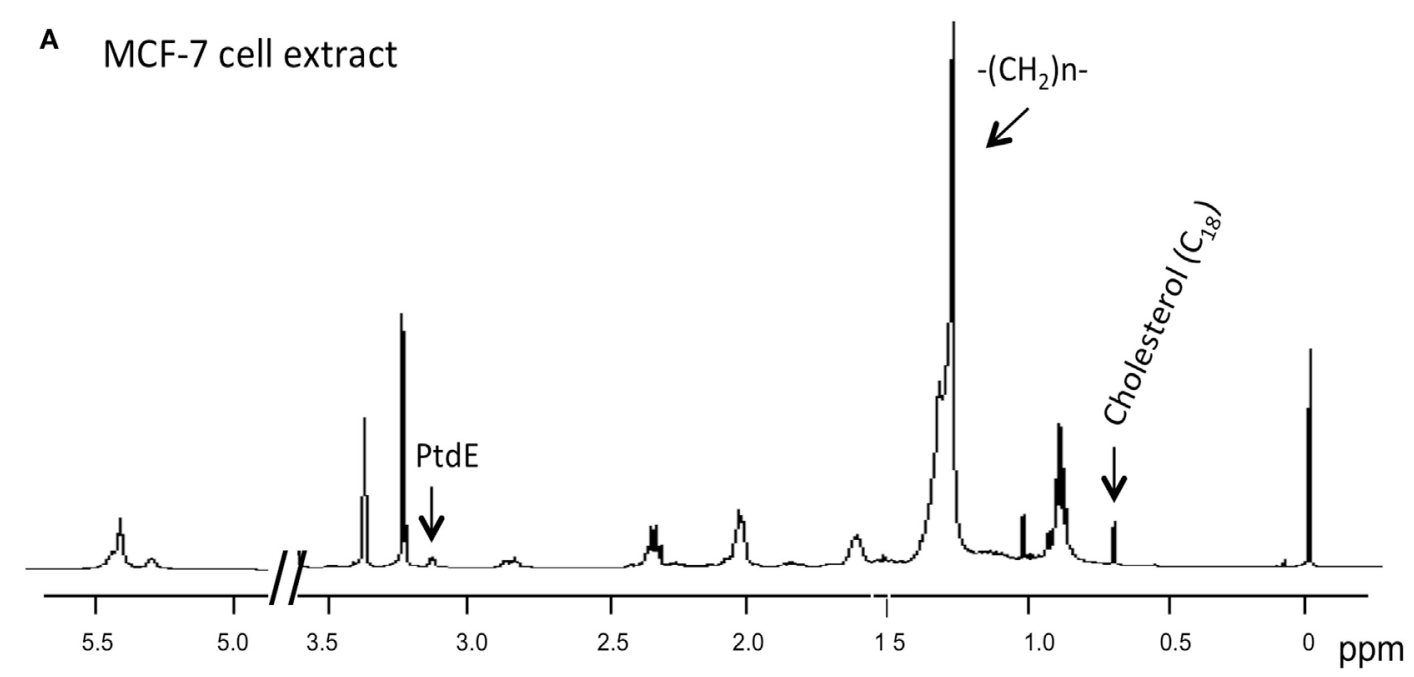

B

MCF-7 tumor extract

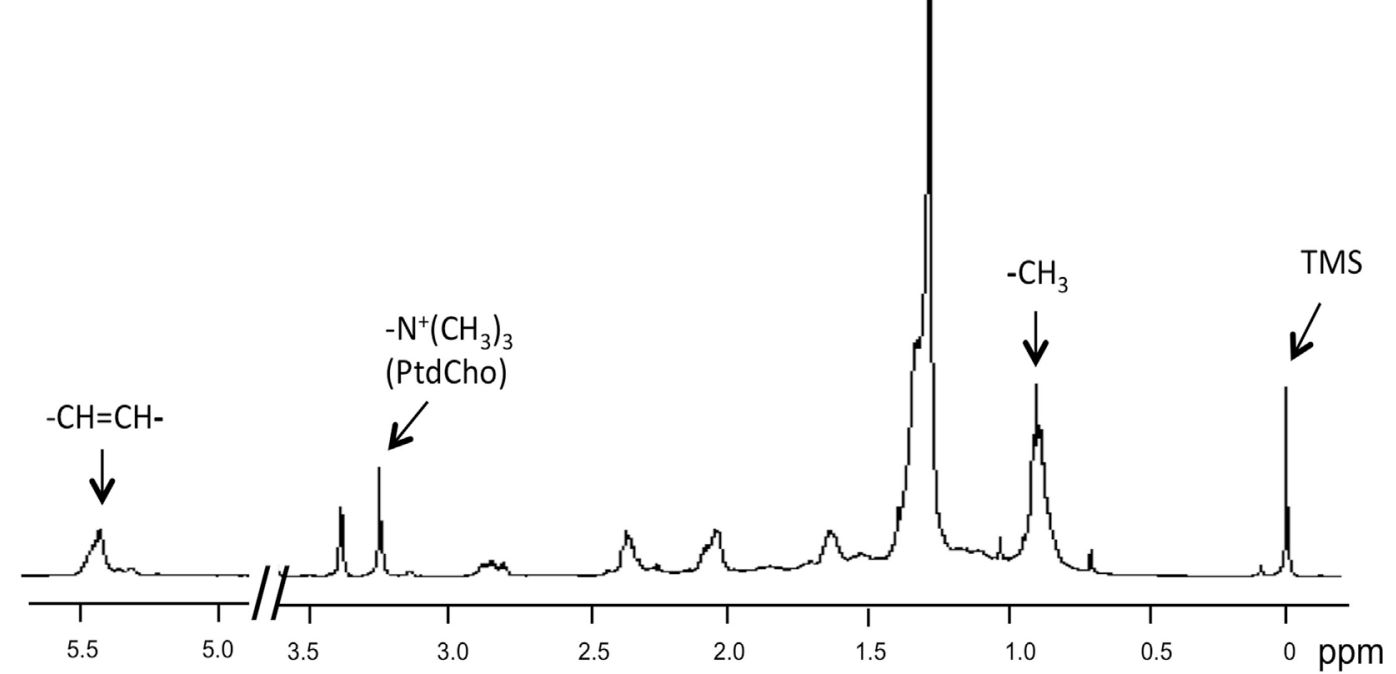

FIGURE 4 | Representative ${ }^{1}$ H MR spectra obtained from lipid-soluble extracts of (A) MCF-7 cells and (B) MCF-7 tumor xenograft. Spectra were acquired on a Bruker Avance 11.7 T spectrometer and are expanded to display signals from 0 to 5.5 ppm (except for 3.7-4.8 ppm). Lipid spectra were acquired with a $30^{\circ}$ flip angle, $10,000 \mathrm{~Hz}$ sweep width, $11.2 \mathrm{~s}$ repetition time, $32 \mathrm{~K}$ block size, and 128 scans. Peak assignments are: TMS, tetramethylsilane (internal standard) at 0 ppm, methyl groups assigned to $\mathrm{C}_{18}$ of cholesterol $\left(\mathrm{C}_{18}\right)$ at $\sim 0.7 \mathrm{ppm}$, the methyl groups $\left(-\mathrm{CH}_{3}\right)$ at $\sim 0.9$ ppm, methylene groups $\left(-\left(\mathrm{CH}_{2}\right) \mathrm{n}-\right)$ at $\sim 1.3 \mathrm{ppm}$, and ethylene groups $(-\mathrm{CH}=\mathrm{CH}-)$ at $\sim 5.4 \mathrm{ppm}$ in acyl chains of lipids, $-\mathrm{CH}_{2}-\mathrm{N}$ in phosphatidylethanolamine at $\sim 3.1$ ppm, and the choline group $\left(-\mathrm{N}^{+}\left(\mathrm{CH}_{3}\right)_{3}\right)$ primarily from phosphatidylcholine at $\sim 3.2 \mathrm{ppm}$. 


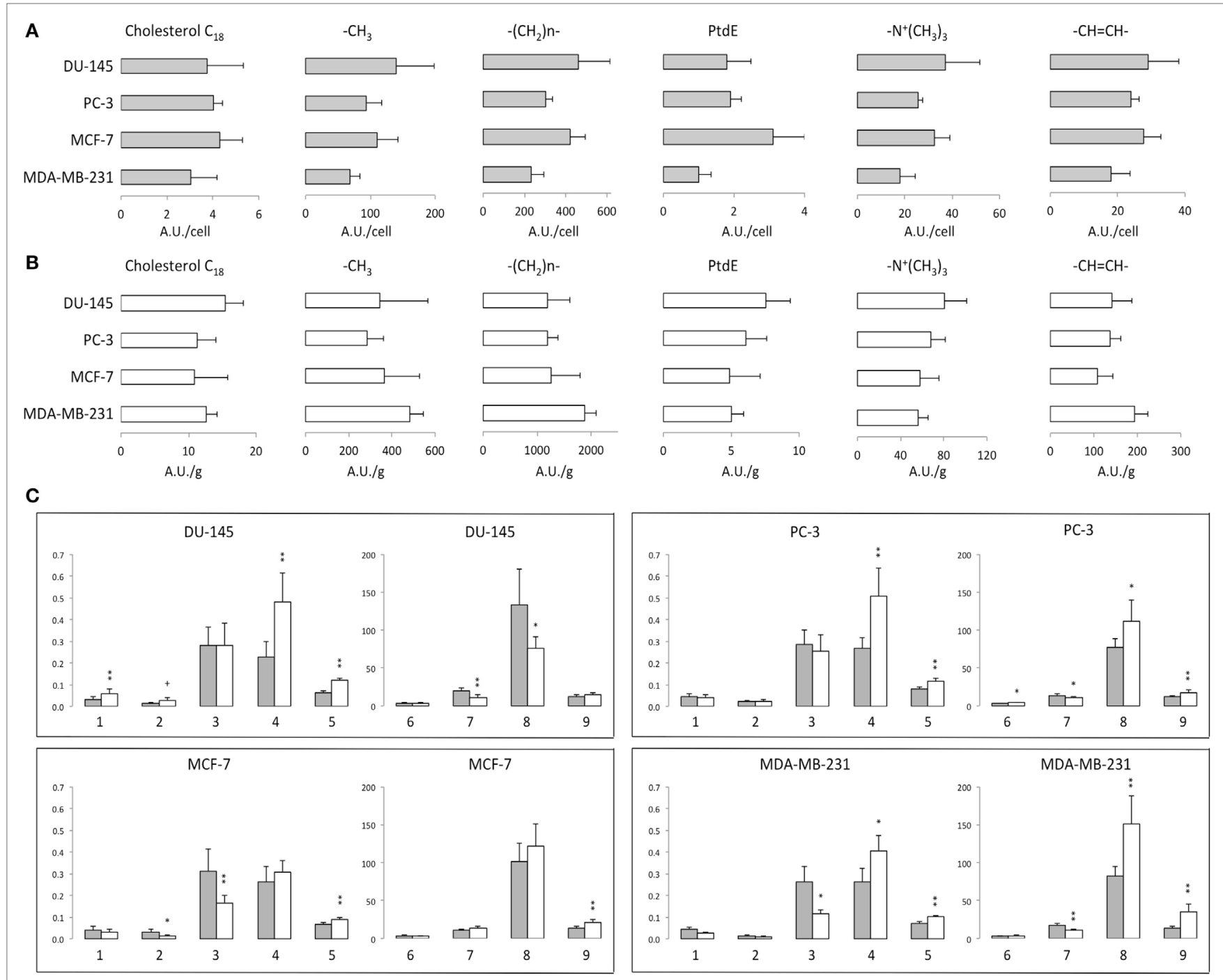

$\square:$ Cells, $\square:$ Tumors

FIGURE 5 | (A) Lipid metabolites in arbitrary unit (A.U.)/cell from ${ }^{1} \mathrm{H}$ MR spectra obtained from lipid-soluble extracts of DU-145, PC-3, MCF-7, and MDA-MB-231 cells. (B) Lipid metabolites in A.U./g from ${ }^{1} \mathrm{H}$ MR spectra obtained from lipid-soluble extracts of DU-145, PC-3, MCF-7, and MDA-MB-231 xenograft models. (C) Ratios of lipid resonances from cells (gray bar) and solid tumors (white bar). 1: $\mathrm{C}_{18} /-\mathrm{CH}_{3}$, 2: phosphatidylethanolamine $(\mathrm{PtdE}) /-\mathrm{CH}_{3}, 3$ : $-\mathrm{N}^{+}\left(\mathrm{CH}_{3}\right)_{3} /-\mathrm{CH}_{3}, 4$ : $-\mathrm{CH}=\mathrm{CH}-/-\mathrm{CH}_{3}, 5:-\mathrm{CH}=\mathrm{CH}-/-\left(\mathrm{CH}_{2}\right) \mathrm{n}-$, 6: $-\left(\mathrm{CH}_{2}\right) \mathrm{n}-/-\mathrm{CH}_{3}, 7:-\mathrm{N}^{+}\left(\mathrm{CH}_{3}\right)_{3} / \mathrm{PtdE}, 8:-\left(\mathrm{CH}_{2}\right) \mathrm{n}-/ \mathrm{C}_{18}, 9:-\left(\mathrm{CH}_{2}\right) \mathrm{n}-/-\mathrm{N}^{+}\left(\mathrm{CH}_{3}\right)_{3}$. Average cell number used for lipid extracts are DU-145: $4.30 \pm 0.96 \times 10^{7}(n=6), \mathrm{PC}-3: 3.85 \pm 0.40 \times 10^{7}(n=6), \mathrm{MCF}-7: 5.07 \pm 0.92 \times 10^{7}(n=7)$, and MDA-MB-231: 4.55 $\pm 0.93 \times 10^{7}(n=4)$. Average tumor weights in gram used for lipid extracts are DU-145: $0.33 \pm 0.07(n=6), \mathrm{PC}-3: 0.34 \pm 0.08(n=7), \mathrm{MCF}-7: 0.27 \pm 0.09(n=9)$, and MDA-MB-231: $0.30 \pm 0.05(n=6)$. Data represent mean $\pm \mathrm{SD} .{ }^{\star \star} P<0.01,{ }^{\star} P<0.05,{ }^{+} P<0.06$ between cells and tumors.

ratios of $-\mathrm{CH}=\mathrm{CH}-/-\left(\mathrm{CH}_{2}\right) \mathrm{n}-,-\mathrm{N}^{+}\left(\mathrm{CH}_{3}\right)_{3} / \mathrm{PtdE},-\left(\mathrm{CH}_{2}\right) \mathrm{n}-/ \mathrm{C}_{18}$, and $-\left(\mathrm{CH}_{2}\right) \mathrm{n}-/-\mathrm{N}^{+}\left(\mathrm{CH}_{3}\right)_{3}$ (Figure 5C).

The degree of lipid unsaturation estimated from $-\mathrm{CH}=\mathrm{CH}-/-$ $\mathrm{CH}_{3}$ or $-\mathrm{CH}=\mathrm{CH}-/-\left(\mathrm{CH}_{2}\right) \mathrm{n}-$ was significantly and consistently higher in tumors than in cells, in all the cell lines (Figure $5 \mathrm{C}$ ). The ratio of $-\left(\mathrm{CH}_{2}\right) \mathrm{n}-/-\mathrm{CH}_{3}$, which is related to the length of fatty acids, was significantly higher in PC-3 tumors than in cells. Ratios of PtdCho $\left(-\mathrm{N}^{+}\left(\mathrm{CH}_{3}\right)_{3}\right)$ to $-\mathrm{CH}_{3}$ were higher in cells than in tumors in the breast cancer cell lines. The $-\mathrm{N}^{+}\left(\mathrm{CH}_{3}\right)_{3} / \mathrm{PtdE}$ ratios were higher in cells than in tumors in the prostate cancer cell lines and the MDA-MB-231 breast cancer cell line but not in MCF-7 cells. Ratios of $-\left(\mathrm{CH}_{2}\right) n-/ \mathrm{C}_{18}$ and $-\left(\mathrm{CH}_{2}\right) \mathrm{n}-/-\mathrm{N}^{+}\left(\mathrm{CH}_{3}\right)_{3}$ were higher in tumors than in cells from more malignant $\mathrm{PC}-3$ and MDA-MB-231 cell lines. $\mathrm{C}_{18} /-\mathrm{CH}_{3}$ and $-\left(\mathrm{CH}_{2}\right) \mathrm{n}-/ \mathrm{C}_{18}$ results showed DU-145 tumors had higher ratio of cholesterol in lipids. Both aggressive PC-3 and MDA-MB-231 cell lines showed similar lipid metabolite changes in cells and tumors.

\section{Levels of Protein That Are Related to Cho Phospholipid Metabolism and Lipid Metabolism}

Immunoblot assays of Chk- $\alpha, \mathrm{cPLA}_{2}, \mathrm{PLD}_{1}$, and FASN antibodies are shown in Figure 6A. A consistently higher expression of 

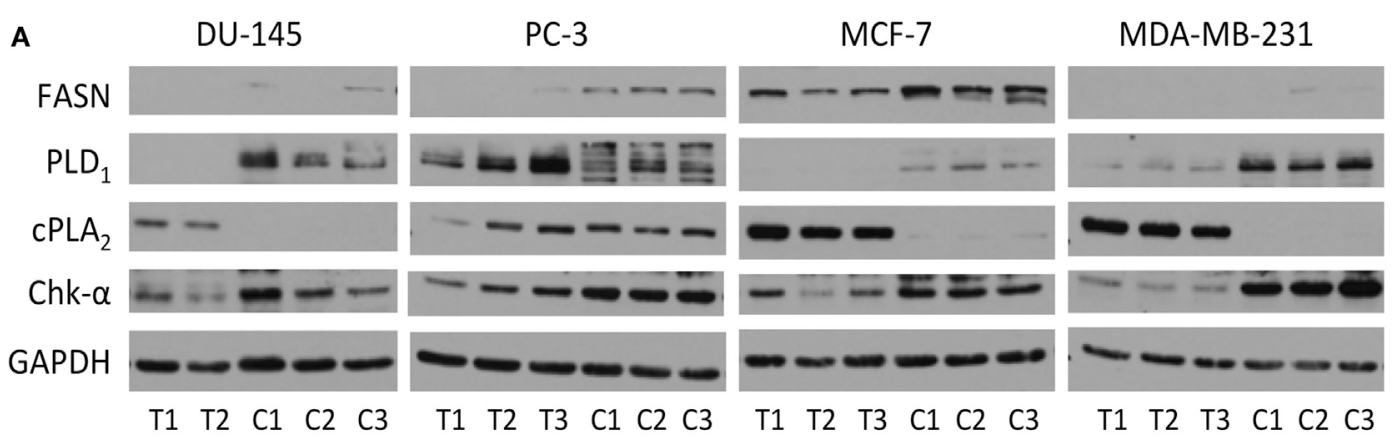

B

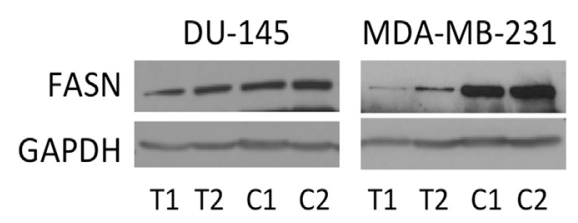

FIGURE 6 | (A) Protein levels of Chk- $\alpha, \mathrm{CPLA}_{2}, \mathrm{PLD}_{1}$, and fatty acid synthase (FASN) determined by immunoblot assays of DU-145, PC-3, MCF-7, and MDAMB-231 cells (marked C) and the tumor xenografts (marked T). (B) Protein levels of FASN in DU-145 and MDA-MB-231 cells (C) and the tumor xenografts (T) were obtained from a separate immunoblot assay with different exposure time. $50 \mu \mathrm{g}$ (A) or 40 $\mathrm{Mg}$ (B) of protein was loaded on a 10\% reducing SDS-PAGE gel. GAPDH protein levels were used for equal loading assessment.

Chk- $\alpha$ was observed in cells compared to solid tumors that was most pronounced in MDA-MB-231 cells.

Higher expression of $\mathrm{CPLA}_{2}$ was observed in DU-145, MDA-MB-231, and MCF-7 tumors compared to the corresponding cells. Like Chk- $\alpha, \mathrm{PLD}_{1}$ was higher in cells than in corresponding tumors with the exception of PC-3 cells.

Overall, levels of FASN were higher in cells than in tumors. The levels of FASN were higher in PC-3 and MCF-7 cells than in the corresponding tumors (Figure 6A). Since levels of FASN in DU-145 and MDA-MB-231 were lower than in the other prostate or breast cancer cell lines, these were not detectable on the same gel (Figure 6A). Therefore, samples from DU-145 and MDA-MB-231 cells and tumors were loaded separately and run with different exposure time (Figure 6B). MDA-MB-231 had higher level of FASN protein in cells than in tumors, and DU-145 had slightly higher or comparable level of FASN in cells than in tumors.

\section{DISCUSSION}

Here, for the first time, we have compared Cho and lipid metabolites in cells maintained in 2-dimensional (2D) monolayer cell culture to the corresponding tumor xenografts and have performed molecular characterization of some of the major enzymes that regulate Cho and lipid metabolism in these cells and tumors. We observed significant differences in metabolite and enzyme expression patterns between cells and tumors confirming the importance of the tumor microenvironment in modulating metabolism. A compendium of factors including vascularization that control substrate delivery and hypoxia, acidic extracellular $\mathrm{pH}(\mathrm{pHe})$, and areas of cell death can influence the enzymes and the metabolites measured in high resolution spectra of tumor extracts.

One common difference to emerge across all the cells lines was a significant decrease of PC and tCho in tumors compared to cells that was consistent with the decrease of Chk- $\alpha$ observed in the tumors compared to the cells. This uniform difference across cell lines is surprising given the differences in vascularization (33), necrosis, hypoxia, and acidosis that have been observed in these tumor models and implicates the high cellular density in tumors, compared to cells in culture, as one mechanism underlying the difference. Additional mechanisms causing the decrease of PC, tCho, and Chk- $\alpha$ in tumors may be related to cancer cell-stromal cell and cancer cell-extracellular matrix (ECM) interactions that are intrinsic to tumor growth in vivo.

The second common difference that emerged from the comparison was a decrease of FASN in tumors compared to cells. Again the uniformity of this observation across the cell lines suggests that the reduction of FASN in tumors was cell density, stromal cell, or ECM related. Given that mechanical stress can create significant changes in cell function (39), it is possible that cancer cells growing within an ECM may demonstrate differences in enzyme expression and consequently metabolism. The uniform decrease of FASN observed in the tumors may also explain the higher unsaturated fatty acids observed in tumors compared to cells, in all the cell lines. Although endogenous and exogenous fatty acids are utilized similarly by MDA-MB- 231 and MCF- 7 cells in culture (40), mouse diet contains higher unsaturated fat (4.7\%) than saturated fat $(0.9 \%)$, which may also contribute to increased unsaturated fatty acids observed in tumors compared to cells.

Another interesting observation that emerged from these studies was that the high PC/GPC ratio associated with aggressive breast and prostate cancer cells in culture $(6,41)$ was not replicated in tumors. This was primarily because of the significant decrease of PC in tumors compared to cells as well as an increase of GPC in tumors compared to cells. Acidic pHe that is frequently observed in tumors (42) has been shown to decrease PC and increase GPC in cells (43). Further characterization, in the future, 
of GPC phosphodiesterase, the enzyme that converts GPC into Cho and glycerol-3-phosphate $(44,45)$ and lysophospholipase, the enzyme that converts lyso-PtdCho to GPC (15), may provide further insights into the differences in GPC between cells and tumors observed here. Increased cell density has also been observed to increase GPC levels (46). We have previously studied PC-3, DU-145, and MDA-MB-231 cells in a cell perfusion system where multilayered cells grow on $3 \mathrm{D}$ beads and have observed similar metabolic profiles as observed in 2D culture, especially in PC-3 (47) and MDA-MB-231 cells (48). Although we cannot rule out differences between $2 \mathrm{D}$ and $3 \mathrm{D}$ culture contributing to the metabolic differences, the differences observed here are more likely due to the tumor microenvironment including cancer cellstromal cell and ECM interactions.

With the exception of the PC-3 cell line, $\mathrm{PLD}_{1}$ was higher in cells compared to tumors, and $\mathrm{CPLA}_{2}$ was higher in tumors compared to cells. In our experience (33), PC-3 tumors are the least vascularized in the four models studied here. The absence of a difference in $\mathrm{PLD}_{1}$ and $\mathrm{CPLA}_{2}$ between the PC-3 cell line compared to the remaining three cell lines may be related to the poor vascularization in PC-3 tumors and the resultant reduction of paracrine signaling from vascular molecules.

Additional characterization, in future studies, of metabolites and cytokines in the tumor interstitial fluid, necrosis, $\mathrm{pH}$, and oxygenation as well as an expanded characterization of the enzymes in Cho and lipid metabolism in culture and in tumors will provide further insights into the mechanisms underlying the differences between cells and tumors observed here. Investigation of metabolite differences between primary tumors and metastatic growth will also provide important insights. Such insights will provide further understanding of the functioning of tumors that

\section{REFERENCES}

1. Gillies RJ, Raghunand N, Karczmar GS, Bhujwalla ZM. MRI of the tumor microenvironment. J Magn Reson Imaging (2002) 16(4):430-50. doi:10.1002/ jmri.10181

2. Mori N, Natarajan K, Chacko VP, Artemov D, Bhujwalla ZM. Choline phospholipid metabolites of human vascular endothelial cells altered by cyclooxygenase inhibition, growth factor depletion, and paracrine factors secreted by cancer cells. Mol Imaging (2003) 2(2):124-30. doi:10.1162/ 153535003322332000

3. Criscitiello C, Esposito A, Curigliano G. Tumor-stroma crosstalk: targeting stroma in breast cancer. Curr Opin Oncol (2014) 26(6):551-5. doi:10.1097/ CCO.0000000000000122

4. Ridgway ND. The role of phosphatidylcholine and choline metabolites to cell proliferation and survival. Crit Rev Biochem Mol Biol (2013) 48(1):20-38. doi:10.3109/10409238.2012.735643

5. Gribbestad IS, Singstad TE, Nilsen G, Fjosne HE, Engan T, Haugen OA, et al. In vivo ${ }^{1} \mathrm{H}$ MRS of normal breast and breast tumors using a dedicated double breast coil. J Magn Reson Imaging (1998) 8(6):1191-7. doi:10.1002/ jmri. 1880080602

6. Aboagye EO, Bhujwalla ZM. Malignant transformation alters membrane choline phospholipid metabolism of human mammary epithelial cells. Cancer Res (1999) 59(1):80-4.

7. Ackerstaff E, Pflug BR, Nelson JB, Bhujwalla ZM. Detection of increased choline compounds with proton nuclear magnetic resonance spectroscopy subsequent to malignant transformation of human prostatic epithelial cells. Cancer Res (2001) 61(9):3599-603.

8. Ramirez de Molina A, Gutierrez R, Ramos MA, Silva JM, Silva J, Bonilla $\mathrm{F}$, et al. Increased choline kinase activity in human breast carcinomas: is critical to developing biomarkers and treatment strategies targeting metabolism.

\section{ETHICS STATEMENT}

All surgical procedures and animal handling were performed in accordance with protocols approved by the Johns Hopkins University Institutional Animal Care and Use Committee and conformed to the Guide for the Care and Use of Laboratory Animals published by the NIH.

\section{AUTHOR CONTRIBUTIONS}

NM; design of the work, the acquisition, analysis, and interpretation of data for the work; drafting the work; final approval of the version to be published; agreement to be accountable for all aspects of the work. FW and TT; the acquisition, analysis, and interpretation of data for the work; revising it critically for important intellectual content; final approval of the version to be published; agreement to be accountable for all aspects of the work. $\mathrm{KG}$ and ZB; design of the work; revising it critically for important intellectual content; final approval of the version to be published; agreement to be accountable for all aspects of the work.

\section{ACKNOWLEDGMENTS}

We thank Dr. V. P. Chacko and Dr. J. Zhang for technical support for the MRS experiments, and Mr. G. Cromwell for assistance with the animal studies. This work was supported by NIH R01 CA73850, R01 CA82337, R01 CA136576, R01 CA138515, and P50 CA103175.

clinical evidence for a potential novel antitumor strategy. Oncogene (2002) 21(27):4317-22. doi:10.1038/si.onc. 1205556

9. Krishnamachary B, Glunde K, Wildes F, Mori N, Takagi T, Raman V, et al. Noninvasive detection of lentiviral-mediated choline kinase targeting in a human breast cancer xenograft. Cancer Res (2009) 69(8):3464-71. doi:10.1158/0008-5472.CAN-08-4120

10. Iorio E, Ricci A, Bagnoli M, Pisanu ME, Castellano G, Di Vito M, et al. Activation of phosphatidylcholine cycle enzymes in human epithelial ovarian cancer cells. Cancer Res (2010) 70(5):2126-35. doi:10.1158/0008-5472. CAN-09-3833

11. Glunde K, Bhujwalla ZM, Ronen SM. Choline metabolism in malignant transformation. Nat Rev Cancer (2011) 11(12):835-48. doi:10.1038/nrc3162

12. Podo F, Canevari S, Canese R, Pisanu ME, Ricci A, Iorio E. MR evaluation of response to targeted treatment in cancer cells. NMR Biomed (2011) 24(6):648-72. doi:10.1002/nbm.1658

13. Kennedy EP. Metabolism of lipides. Annu Rev Biochem (1957) 26:119-48. doi:10.1146/annurev.bi.26.070157.001003

14. Aoyama C, Liao H, Ishidate K. Structure and function of choline kinase isoforms in mammalian cells. Prog Lipid Res (2004) 43(3):266-81. doi:10.1016/ j.plipres.2003.12.001

15. Glunde K, Jie C, Bhujwalla ZM. Molecular causes of the aberrant choline phospholipid metabolism in breast cancer. Cancer Res (2004) 64(12):4270-6. doi:10.1158/0008-5472.CAN-03-3829

16. Chen JH, Mehta RS, Baek HM, Nie K, Liu H, Lin MQ, et al. Clinical characteristics and biomarkers of breast cancer associated with choline concentration measured by ${ }^{1} \mathrm{H}$ MRS. NMR Biomed (2011) 24(3):316-24. doi:10.1002/ nbm.1595

17. Glunde K, Raman V, Mori N, Bhujwalla ZM. RNA interference-mediated choline kinase suppression in breast cancer cells induces differentiation and 
reduces proliferation. Cancer Res (2005) 65(23):11034-43. doi:10.1158/00085472.CAN-05-1807

18. Mori N, Glunde K, Takagi T, Raman V, Bhujwalla ZM. Choline kinase down-regulation increases the effect of 5-fluorouracil in breast cancer cells. Cancer Res (2007) 67(23):11284-90. doi:10.1158/0008-5472.CAN-07-2728

19. Moestue SA, Borgan E, Huuse EM, Lindholm EM, Sitter B, Borresen-Dale AL, et al. Distinct choline metabolic profiles are associated with differences in gene expression for basal-like and luminal-like breast cancer xenograft models. BMC Cancer (2010) 10:433. doi:10.1186/1471-2407-10-433

20. Noh DY, Ahn SJ, Lee RA, Park IA, Kim JH, Suh PG, et al. Overexpression of phospholipase D1 in human breast cancer tissues. Cancer Lett (2000) 161(2):207-14. doi:10.1016/S0304-3835(00)00612-1

21. Gadiya M, Mori N, Cao MD, Mironchik Y, Kakkad S, Gribbestad IS, et al. Phospholipase D1 and choline kinase-alpha are interactive targets in breast cancer. Cancer Biol Ther (2014) 15(5). doi:10.4161/cbt.28165

22. Dhingra S, Rodriguez ME, Shen Q, Duan X, Stanton ML, Chen L, et al. Constitutive activation with overexpression of the mTORC2-phospholipase D1 pathway in uterine leiomyosarcoma and STUMP: morphoproteomic analysis with therapeutic implications. Int J Clin Exp Pathol (2011) 4(2):134-46.

23. Shen Q, Stanton ML, Feng W, Rodriguez ME, Ramondetta L, Chen L, et al. Morphoproteomic analysis reveals an overexpressed and constitutively activated phospholipase D1-mTORC2 pathway in endometrial carcinoma. Int J Clin Exp Pathol (2010) 4(1):13-21.

24. Eyster KM. The membrane and lipids as integral participants in signal transduction: lipid signal transduction for the non-lipid biochemist. Adv Physiol Educ (2007) 31(1):5-16. doi:10.1152/advan.00088.2006

25. Varga T, Nagy L. Nuclear receptors, transcription factors linking lipid metabolism and immunity: the case of peroxisome proliferator-activated receptor gamma. Eur J Clin Invest (2008) 38(10):695-707. doi:10.1111/ j.1365-2362.2008.02022.x

26. Shurbaji MS, Kalbfleisch JH, Thurmond TS. Immunohistochemical detection of a fatty acid synthase (OA-519) as a predictor of progression of prostate cancer. Hum Pathol (1996) 27(9):917-21. doi:10.1016/S0046-8177(96)90218-X

27. Gansler TS, Hardman W III, Hunt DA, Schaffel S, Hennigar RA. Increased expression of fatty acid synthase (OA-519) in ovarian neoplasms predicts shorter survival. Hum Pathol (1997) 28(6):686-92. doi:10.1016/ S0046-8177(97)90177-5

28. Milgraum LZ, Witters LA, Pasternack GR, Kuhajda FP. Enzymes of the fatty acid synthesis pathway are highly expressed in in situ breast carcinoma. Clin Cancer Res (1997) 3(11):2115-20.

29. Rashid A, Pizer ES, Moga M, Milgraum LZ, Zahurak M, Pasternack GR, et al. Elevated expression of fatty acid synthase and fatty acid synthetic activity in colorectal neoplasia. Am J Pathol (1997) 150(1):201-8.

30. Wang Y, Kuhajda FP, Li JN, Pizer ES, Han WF, Sokoll LJ, et al. Fatty acid synthase (FAS) expression in human breast cancer cell culture supernatants and in breast cancer patients. Cancer Lett (2001) 167(1):99-104. doi:10.1016/ S0304-3835(01)00464-5

31. Menendez JA, Lupu R. Fatty acid synthase and the lipogenic phenotype in cancer pathogenesis. Nat Rev Cancer (2007) 7(10):763-77. doi:10.1038/nrc2222

32. Mashima T, Seimiya H, Tsuruo T. De novo fatty-acid synthesis and related pathways as molecular targets for cancer therapy. Br JCancer (2009) 100(9):1369-72. doi:10.1038/sj.bjc.6605007

33. Bhujwalla ZM, Artemov D, Natarajan K, AckerstaffE, Solaiyappan M. Vascular differences detected by MRI for metastatic versus nonmetastatic breast and prostate cancer xenografts. Neoplasia (2001) 3(2):143-53. doi:10.1038/ sj.neo.7900129

34. Mori N, Gadiya M, Wildes F, Krishnamachary B, Glunde K, Bhujwalla ZM. Characterization of choline kinase in human endothelial cells. NMR Biomed (2013) 26(11):1501-7. doi:10.1002/nbm.2983

35. Sze DY, Jardetzky O. Characterization of lipid composition in stimulated human lymphocytes by 1H-NMR. Biochim Biophys Acta (1990) 1054(2):198-206. doi:10.1016/0167-4889(90)90241-5
36. Casu M, Anderson GJ, Choi G, Gibbons WA. Nmr lipid profiles of cells, tissues and body-fluids0.1. $1 \mathrm{~d}$ and $2 \mathrm{~d}$ proton Nmr of lipids from rat-liver. Magn Reson Chem (1991) 29(6):594-602. doi:10.1002/mrc.1260290610

37. Pollesello P, Eriksson O, Kvam BJ, Paoletti S, Saris NE. 1H-NMR studies of lipid extracts of rat liver mitochondria. Biochem Biophys Res Commun (1991) 179(2):904-11. doi:10.1016/0006-291X(91)91904-Q

38. Le Moyec L, Legrand O, Larue V, Kawakami M, Marie JP, Calvo F, et al. Magnetic resonance spectroscopy of cellular lipid extracts from sensitive, resistant and reverting K562 cells and flow cytometry for investigating the P-glycoprotein function in resistance reversion. NMR Biomed (2000) 13(2): 92-101. doi:10.1002/(SICI)1099-1492(200004)13:2<92::AID-NBM615>3.0. $\mathrm{CO} ; 2-\mathrm{R}$

39. Yoon AR, Stasinopoulos I, Kim JH, Yong HM, Kilic O, Wirtz D, et al. COX-2 dependent regulation of mechanotransduction in human breast cancer cells. Cancer Biol Ther (2015) 16(3):430-7. doi:10.1080/15384047. 2014.1003004

40. Hopperton KE, Duncan RE, Bazinet RP, Archer MC. Fatty acid synthase plays a role in cancer metabolism beyond providing fatty acids for phospholipid synthesis or sustaining elevations in glycolytic activity. Exp Cell Res (2014) 320(2):302-10. doi:10.1016/j.yexcr.2013.10.016

41. Iorio E, Mezzanzanica D, Alberti P, Spadaro F, Ramoni C, D'Ascenzo S, et al. Alterations of choline phospholipid metabolism in ovarian tumor progression. Cancer Res (2005) 65(20):9369-76. doi:10.1158/0008-5472.CAN-05-1146

42. Gillies RJ, Bhujwalla ZM, Evelhoch J, Garwood M, Neeman M, Robinson SP, et al. Applications of magnetic resonance in model systems: tumor biology and physiology. Neoplasia (2000) 2(1-2):139-51. doi:10.1038/sj.neo. 7900076

43. Galons JP, Job C, Gillies RJ. Increase of GPC levels in cultured mammalian cells during acidosis. A 31P MR spectroscopy study using a continuous bioreactor system. Magn Reson Med (1995) 33(3):422-6. doi:10.1002/mrm. 1910330317

44. Cao MD, Dopkens M, Krishnamachary B, Vesuna F, Gadiya MM, Lonning $\mathrm{PE}$, et al. Glycerophosphodiester phosphodiesterase domain containing 5 (GDPD5) expression correlates with malignant choline phospholipid metabolite profiles in human breast cancer. NMR Biomed (2012) 25(9):1033-42. doi: $10.1002 / \mathrm{nbm} .2766$

45. Stewart JD, Marchan R, Lesjak MS, Lambert J, Hergenroeder R, Ellis JK, et al. Choline-releasing glycerophosphodiesterase EDI3 drives tumor cell migration and metastasis. Proc Natl Acad Sci U S A (2012) 109(21):8155-60. doi:10.1073/pnas.1117654109

46. Lyng H, Sitter B, Bathen TF, Jensen LR, Sundfor K, Kristensen GB, et al. Metabolic mapping by use of high-resolution magic angle spinning $1 \mathrm{H} M \mathrm{MR}$ spectroscopy for assessment of apoptosis in cervical carcinomas. BMC Cancer (2007) 7:11. doi:10.1186/1471-2407-7-11

47. Shah T, Wildes F, Kakkad S, Artemov D, Bhujwalla ZM. Lymphatic endothelial cells actively regulate prostate cancer cell invasion. NMR Biomed (2016) 29(7):904-11. doi:10.1002/nbm.3543

48. Glunde K, Ackerstaff E, Natarajan K, Artemov D, Bhujwalla ZM. Real-time changes in $1 \mathrm{H}$ and 31P NMR spectra of malignant human mammary epithelial cells during treatment with the anti-inflammatory agent indomethacin. Magn Reson Med (2002) 48(5):819-25. doi:10.1002/mrm.10295

Conflict of Interest Statement: The authors declare that the research was conducted in the absence of any commercial or financial relationships that could be construed as a potential conflict of interest.

Copyright $\odot 2016$ Mori, Wildes, Takagi, Glunde and Bhujwalla. This is an open-access article distributed under the terms of the Creative Commons Attribution License (CC BY). The use, distribution or reproduction in other forums is permitted, provided the original author(s) or licensor are credited and that the original publication in this journal is cited, in accordance with accepted academic practice. No use, distribution or reproduction is permitted which does not comply with these terms. 